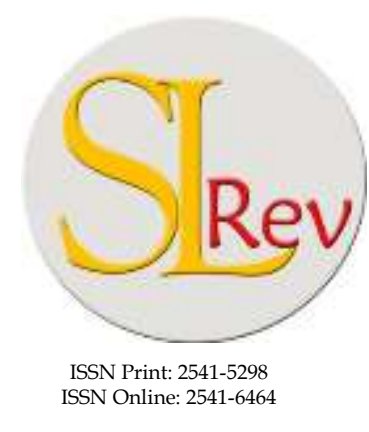

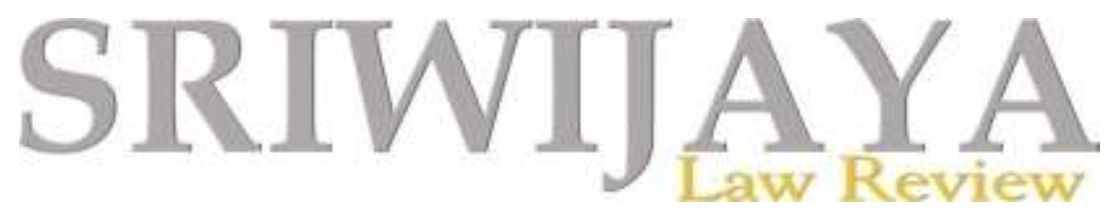

Editorial Office: Faculty of Law, Sriwijaya University, Jalan Srijaya Negara, Palembang, South Sumatra 30139, Indonesia. Phone: +62711-580063Fax: +62711-581179

E-mail: sriwijayalawreview@unsri.ac.id | sriwijayalawreview@gmail.com Website: http://journal.fh.unsri.ac.id/index.php/sriwijayalawreview

\title{
Separation of Powers Under the 1999 Nigerian Constitution: The Core Legal Dilemmas
}

\section{Olusola Babatunde Adegbite,* Oreoluwa Omotayo Oduniyi,* and Jubril Akinwunmi Farinde*}

\begin{abstract}
At the core of Nigeria's constitutional practice lies the doctrine of separation of powers. The application of the principle is such that power under Nigeria's presidential cum federal system is delineated both horizontally and vertically. Even though the doctrine has a major feature of every constitution in the world, its implementation does not seem satisfactory given the insults that have been carried out by successive governments. This paper examines the doctrine of separation of powers and its complicatedness as regards to its practice in Nigeria's constitutional democracy. Reflecting on the history of Nigeria, this paper will discuss the eroded implementation of the principle of separation. As a result, it seems to be that the concept of "separation" is not going well and tends to fuse the function of executive and legislative institutions. In this situation, the principle is in a dilemma. This paper further offers a flicker of hope by pointing to the fact that all hopes do not appear lost, as the Judiciary still maintains some level of 'separateness,' except that only time will tell as to how much this lasts.
\end{abstract}

Keywords: Constitution; Democracy; Nigeria; Separation of Powers.

\section{ARTICLE HISTORY:}

\section{DOI: 10.28946/slrev.Vol3.Iss2.281.pp235-252}

Received: May 6, 2019;

Reviewed: Jul 16, 2019;

Accepted: Jul 28, 2019;

Published: Jul 31, 2019.

$$
\begin{aligned}
& \text { Faculty of Law, Obafemi Awolowo University, } \\
& \text { Ile-Ife, Nigeria. } \quad \text { E-mail: } \begin{array}{r}
\text { oadeg- } \\
\text { adeg- } \\
\text { bite@oauife.edu.ng; } \\
\text { bite@law.cardozo.yu.edu. }
\end{array}
\end{aligned}
$$

\section{INTRODUCTION}

A critical feature of every modern Constitution is the separation of powers (hereinafter referred to as the doctrine) amongst the different organs or branches of government. The doctrine not only serves as a guide to the proper organization of powers and government, as well as being the most effective embodiment of the spirit underlying it, ${ }^{1}$ it is further founded on the existential fear that to concentrate powers in just one branch, person, or group of persons is tantamount to abuse of power, arbitrariness, and tyranny. From its humble origin, the doctrine has had a significant influence on the running of governmental affairs and has helped put in check the morbid desires of men of ill will. However, in lieu of rapid political development of the $21^{\text {st }}$ century, its relevance as the touch-bearer of contemporary constitutional governance has come under severe attack.

Right from independence, successive governments in Nigeria have engineered

1 M.J.C. Vile, Constitutionalism and the Separation of Powers, (Indianapolis: Liberty Funds Inc., $2^{\text {nd }}$ edn., 1998), pp1-443. 
different constitutions all providing for the doctrine of separation of powers. ${ }^{2}$ The latest is the Constitution of the Federal Republic of Nigeria, 1999. ${ }^{3}$ Notwithstanding the existence of the doctrine in these documents, the practical reality is that power rather than being 'separated' has not only enjoyed an appearance of 'fusion', but most pathetically has been personalised by the Executive branch in such a manner as to make it seem as representing government in totality. This scenario has also been replicated at the other two levels of government, i.e., the State and Local governments. Against this background, a fast-maturing notion today by legal scholars such as Calabresi is that the doctrine is in crisis. ${ }^{4}$ The position is that both Executive and Legislature are so entangled in each other functions. So, both institutions have blurred the lines of separation. ${ }^{5}$ The refer to examples such as the Executive encroaching on the function of law-making through the issuance of executive orders and proclamations, as well as the Legislature getting in-

2 From 1954 when a new era of Self-government emerged, the Nigerian State has engineered seven federal constitutions namely the 1954 Constitution, the 1960 Independence Constitution, the 1963 Republication Constitution, the 1979 Constitution, the 1989 Constitution, the 1995 Constitution, and the 1999 Constitution. It is worth stating that both the 1989 and the 1995 Constitution were inchoate documents, and never became fully-fledged Constitutions. For an extensive overview on the trajectory of Nigerian Constitutions, see generally A. Gboyega, 'The Making of the Nigerian Constitution,' in O. Oyediran (ed.), Nigerian Government \& Politics under Military Rule, (Lagos: Friends Foundation Publishers Ltd., 1988), pp1-319.

3 This Constitution is more notoriously referred to as Decree No.24 of 1999, as the last act of Military law-making by the administration of General Abdulsalami Abubakar.

4 S.G. Calabresi, M.E. Berghausen, and S. Albertson, "The Rise and Fall of the Separation of Powers," (2012), 106 (2), Northwestern University Law Review, pp527-550.

$5 \quad$ Note 4. volved in executive functions through congressional oversight activities as pointers to the erosion of the doctrine. ${ }^{6}$ In order to thematically address these issues as well as deepen the ongoing conversation, this Paper will be examining the doctrine first from an historical context, to discussing its seeming decline under Nigeria's Constitutional framework, towards determining how the country's constitutional experience can be the better for it.

\section{DEFINITION AND HISTORY OF THE DOCTRINE OF SEPARATION OF POWERS}

The doctrine of separation of powers articulates that each branch of government is distinct, independent, and not seen as exercising the powers of others. ${ }^{7}$ It has also been described to mean that one branch should not control or interfere with the work of another. ${ }^{8}$ The separation of legislative, executive, and judiciary powers is a key principle in most democratic Constitutions. ${ }^{9}$ Different arguments have been pushed concerning the allocation of governmental powers following this doctrine. The functionalists argue that most Constitutions do not say much about the distribution of

Note 4.

A. Hamilton, J. Madison, and J. Jay, The Federalist: A Collection of Essays, Written in Favour of the New Constitution, as Agreed upon by the Federation Convention September 17, 1787, (The Lawbook Exchange Ltd., 2005), pp1-628.

8 A.W. Bradley and K.D. Ewing, Constitutional and Administrative Law, (Longman, $13^{\text {th }}$ edn., 2003), p84.

9 K. Fuchs and F. Herold, "The Costs and Benefits of a Separation of Powers: An Incomplete Contracts Approach," (2011), 13 (1), American Law and Economics Review, pp131-167. 
powers amongst different branches of government. ${ }^{10}$

The early origin of the doctrine dated back to the $4^{\text {th }}$ century B.C. when Aristotle, in his treatise 'Politics', advocated for three agencies of government i.e. the general assembly, the public officials, and the judiciary, to be the structure of the State. ${ }^{11}$ Aristotle tried to make distinctions between the function and authority of these three branches that make up a government. ${ }^{12}$ After the fall of the Roman Empire, and with Europe divided into several nation-states, most of the power of the state was domiciled in tyrannical monarchs, except for the English society where the Parliament had emerged. Following development under English constitutional rule, John Locke developed the idea of the three branches of government which he gave the titles Executive, Legislature, and Judiciary. ${ }^{13}$ According to Locke to secure the gains of liberty, power must not be seen as concentrated in one man, but in separate hands or institutions. ${ }^{14} \mathrm{He}$ was of the view that the greatest danger to democratic rule would be to situate all powers in the hands of the legislature as they may remove themselves from the purview of the law, with

10 P. L. Strauss, 1984, "The Place of Agencies in Government: Separation of Powers and the Fourth Branch," Columbia Law Review, 84, pp573-597.

11 Aristotle, Politics, (Indianapolis: Hackett Publishing Co., Translated by C.D.C Reeve 1998), pp1-384.

12 Note 11. After Aristotle's ground work, James Harrington an English scholar espoused the doctrine in his work, 'Common Wealth of Oceana', (1656), which romanticized a utopian political system built on the separation of powers.

13 J. Locke, Treatise of Civil Government, 1690, (Cambridge: Cambridge University Press, Peter Laslett ed.,1988), pp366-367

14 Note 13. See also A. Appodarai, The Substance of Politics, (Oxford: Oxford University Press, 2001), pp1-602. the evil that it makes the citizens subject to the arbitrariness and whimsical idiosyncrasies of men of evil intentions. ${ }^{15}$ However, a stoic opponent of the doctrine is Thomas Hobbes who in his vitriolic denouncement of the doctrine argued that governmental powers were indivisible and inseparable. ${ }^{16}$

In the long history of constitutional thoughts, the opinion of other leading constitutionalists has also helped to shape the development of the doctrine. The trio of Alexander Hamilton, James Madison, and Thomas Jefferson, stood out in their generation as men equipped with extraordinary foresight and vision, that saw them produce new understanding of political power and the institution of government among the people. ${ }^{17}$ According to them, "If Men were Angels, no government would be necessary, and if Angels were to govern men, neither external nor internal controls on government would be necessary". ${ }^{18}$ They further stated that, "In framing a government which is to be administered by men over men, the great difficulty lies in this - You must first enable the government to control the governed, and in the next place oblige it to control itself'. ${ }^{19}$ They then concluded that, "For one, a dependence on the people is the primary control on the government, but experience has taught mankind the necessity of auxiliary precautions". ${ }^{20}$

15 Note 14.

16 T. Hobbes, Leviathan 1651 - (Cambridge Text in the History of Political Thought, (Cambridge: Cambridge University Press, Richard Tuck Ed., 1996), pp1-510.

17 C.D. Bowen, Miracle at Philadelphia: The Story of the Constitutional Convention May - September 1787, (Back Bay Books, 1986), pp1-333.

18 J. Madison, Federalist Papers No. 51, (1788).

19 Note 18.

20 Note 18. 
There were, however, aspects of divergence in their views. James Madison, for instance, was of the opinion that self-interest was an inevitable force in check-mating the political behavior of leaders. ${ }^{21}$ Extending this argument, he said, "as there is a degree of depravity in mankind which requires a certain degree of circumspection and distrust, so there are other qualities in human nature, which justify a certain portion of esteem and confidence". ${ }^{22} \mathrm{He}$ then goes ahead to add that the "aim of every political constitution is, or ought to be, first to obtain for ruler men who possess the most wisdom to discern, the most virtue to pursue, and the common good of society; and in the next place, to take the most effectual precautions for keeping them virtuous while they continue to hold public trust". ${ }^{23}$ Thus, though Madison agreed with Locke that where power is domiciled in just one branch of government, tyrannical rule is the result; ${ }^{24}$ he was also of the opinion that such men may possess certain inherent qualities that may be enough to keep them in check.

However, his fellow Federalists compatriots disagreed with him, saying selfinterest all by itself is not enough. According to Hamilton, "The supposition of universal venality in human nature, is little less an

21 Note 18.

22 Note 18.

23 J. Madison, Federalist Papers, No. 57, (1788).

24 In making this point, he opined as follows, "The accumulation of all powers, legislative, executive, and judiciary, in the same hands, whether of one, a few, or many, and whether hereditary, selfappointed, or elective, may justly be pronounced the very definition of tyranny. Were the federal Constitution, therefore, really chargeable with this accumulation of power, or with a mixture of powers, having a dangerous tendency to such an accumulation, no further arguments would be necessary to inspire a universal reprobation of the system". See J. Madison, The Federalist, No. 47, (Clinton Rossiter ed., 1961), pp1-560. error in political reasoning than the supposition of universal rectitude" ${ }^{25}$ Thomas Jefferson, however, appears to depart from the position of his fellow intellectuals radically. Expressing rather iconoclastic thoughts, he was of the opinion that, "turbulence is productive of good, it prevents the degeneracy of government, and nourishes a general attention to the public affairs. I hold that a little rebellion now and then is a good thing". ${ }^{26}$ The sum of the thoughts of these outstanding intellectuals, is that the only security against a gradual concentration of powers in one hand lies in granting unto the three branches of government the constitutional means to resist the encroachment of others. ${ }^{27}$ In this wise, constitutional safeguard are designed in a manner that the defense provided for, is commensurate to the danger of attack, such that reckless ambition in one branch is countered effectively by potent checks in the other. ${ }^{28}$

Following the works of the French Political theorist and philosopher, Baron de Montesquieu, separation of powers gained momentum as a major pillar of Dicey's Rule of Law, ${ }^{29}$ particularly one that will serve as a bulwark against the centralization of power in the hands of a single individual, group, or institution. ${ }^{30}$ According to Montesquieu who

25 A. Hamilton, The Federalist Papers, No.76

26 See Letter to Madison, Jan. 30, 1787, in The Portable Thomas Jefferson 416-410 (M. Peterson ed. 1975)

27 J. Madison, n. 15.

28 Note 27.

29 A. V. Dicey, Introduction to the Study of the Law of the Constitution, (Macmillan Publishers, $10^{\text {th }}$ Edn., 1959), p424.

30 Baron de Montesquieu, The Spirit of Laws, (Frank Neuman ed., Encyclopaedia Britannica edn., 1952) (1748). Edition published in Paris in 1877, 11.6. The title of the chapter is 'De la constitution d' Angleterre'; See also Charles de Montesquieu, The 
distastefully resented the idea of absolutism, where powers are fused the consequences are condemned to be dire. ${ }^{31}$ Montesquieu's postulations is rooted in the twin idea of rule of law and liberty as resistance against the tyrannically governments that were the order of the day in then Continental Europe. ${ }^{32}$ However, for Montesquieu executive power was a power to execute all laws except the exercise of judicial powers. ${ }^{33}$ This was a position radically different from Locke's argument that executive power and judicial powers were historically combined as one. The same sentiment was shared by the

Spirit of Laws - Cambridge Text in the History of Political Thought, (Cambridge: Cambridge University Press, A. M. Cohler et al. eds., 1989), pp1-747.

31 Note 32. Montesquieu expressed this thinking in the following words, "When the legislative and executive powers are united in the same person, or in the same body of magistrates, there can be no liberty, because apprehensions may arise, lest the same monarch or senate should enact tyrannical laws, to execute them in a tyrannical manner. Again, there is no liberty if the judicial power be not separated from the legislative and executive. Where it joined with the legislative, the life and liberty of the subject would be exposed to arbitrary control: for the judge would then be the legislator. Where it joined with the executive power, the judge might behave with violence and oppression. Miserable indeed would be the case, were the same man or the same body, whether of the nobles or of the people, to exercise those three powers, that of enacting laws, that of executing the public resolutions and that of judging the crimes or differences of individuals". However, his notion of separation of powers has been heavily criticised. See L. Claus, 'Montesquieu's Mistakes and the True Meaning of Separation of Powers', (2005), 25, Oxford Journal of Legal Studies, p419.

32 From the rule of Alexander, the great down to Napoleon Bonaparte, the rise of tyranny was a part of the political order in early medieval Europe.

33 Montesquieu cited structural reasons for why the judicial should be separated from the executive. For example, he pointed out that in monarchic states, the prince was the prosecutor who punished. If the same prince also judged the case, the prince "would be both judge and party," and that clearly would be improper.
English thinker, Blackstone who postulated that executive power was the power to execute laws. ${ }^{34} \mathrm{He}$ added that, "executive powers of the laws is lodged in a single person (in England); they have all the advantages of strength and dispatch". ${ }^{35}$ This position had been hinged on the fact that the concept of liberty had by that time come to enjoy a pride of place under English Constitutional framework, a development that was helped greatly by the inspiration that came from two leading human rights ${ }^{36}$ documents of that time, the English Bill of Rights 1686, and the Magna Carta 1215. ${ }^{37}$ The influence of these two landmark documents pushed for a system in which the powers of the English Monarch which was hitherto absolute and unchallengeable, would be limited and a part exercised by the English

34 In echoing Montesquieu thoughts, Sir William Blackstone noted as follow, "In all tyrannical government the supreme magistery, or the right both of making and enforcing the laws, is vested in one and the same man, or one and the same body of men; and whenever these two powers are united together, there can be no public liberty. The magistrate may enact tyrannical laws, and execute them in a tyrannical manner, since he is possessed in quality of dispenser of justice, with all the quality of dispenser of justice, with all the power which he as legislator thinks proper to give himself. But, where the legislature and executive authority are in distinct hands, the former will take care not to entrust the later with so large a power, as may tend to the subversion of its own independence, and therewith of the liberty of the subject". See William Blackstone, Commentaries on the Laws of England, (Clarendon Press, $1^{\text {st }} \mathrm{ed}$, 1765), pp 259-260.

35 Note 34.

36 Nurhidayatuloh, N., \& Febrian, F., 2019, “ASEAN and European Human Rights Mechanisms, What Should be Improved?," Padjadjaran Journal of Law, 6(1), pp151-167.

37 English Constitutional history credits both the Bill of Rights and the Magna Carta with shaping the development of constitutional rights in the British Empire and the gradual dismantling of the quiet authoritarianism of age-long Monarch that had ruled with a fiat. 
Parliament. ${ }^{38}$ Thus, with the birth of the Crown and Parliament as two organs of the then English Constitutional structure, Montesquieu through his postulations advocated inclusion of the Judiciary, to be the third leg of the tripod.

In most modern governments, power in this regard is of three species vested in distinct branches of government i.e. the Legislature which makes the law, the Executive which executes the law, and the Judiciary which interprets the law. ${ }^{39}$ Where this departmentalization is properly in place, the argument is that government will run smoothly. ${ }^{40}$ From its early practice, the doctrine of separation of powers is now a landmark feature of the US Constitution, ${ }^{41}$ and has emerged as an important part of the general understanding of the doctrine of constitutionalism. ${ }^{42}$ Not only does it advocate that

38 As a matter of fact, this era saw the quick rise of the corollary doctrine of 'Parliamentary Supremacy', in which for the first time, the powers of the Crown was questioned and the authority of the Parliament to make any law, amend any law, or even repeal any law, was seen as final.

39 For an extensive read, see generally O. Abifarin, Essays on Constitutional and Administrative Law under the 1999 Constitution, (Kaduna: Mofolayomi Press, 2000), p5; K.M. Mowe, Constitutional Law in Nigeria, (Lagos: Malthouse Press Ltd, 2008), p23.

40 N. Barber, 2001, "Prelude to the Separation of Powers," Cambridge Law Journal, 60, p59.

41 G. Casper, "An Essay in Separation of Powers: Some Early Versions and Practices," (1989), 30, William and Mary Law Review, p211; L. Lessig and C.R. Sunstein, "The President and the Administration," (1994), 93, Columbia Law Review, p1.

42 J. Waldron, 'Constitutionalism: A Skeptical View', in T. Christiano and J. Christman (eds.), Contemporary Debates in Political Philosophy, (2009), pp270-273; E. Carolan, The New Separation of Powers: A Theory of the Modern State, (Oxford: Oxford University Press, 2009), p18. each branch of government is independent, ${ }^{43}$ it masterly annuls the possibility of such powers being concentrated in just one person, ${ }^{44}$ as a way of protecting liberty, ${ }^{45}$ and guarantee the security of the state. ${ }^{46}$ For example, in modern constitutional democracies, the independence of the judiciary is a signpost of the maturity of democratic rule. ${ }^{47}$

\section{THE NIGERIAN CONSTITUTIONAL MODEL OF THE DOCTRINE OF SEP- ARATION OF POWERS}

The Doctrine of separation of powers is part of the heart and soul of Nigeria's 1999 Constitution. This Constitution, which is the country's fundamental law makes an effort to intelligently allocate powers and functions amongst the three branches of government and their various subsidiaries. ${ }^{48}$ The twin objectives of the incorporation of the doctrine into the country's constitutional framework is to ensure efficiency in governance delivery and prevent the exercise of arbitrary power. ${ }^{49}$

Under the 1999 Nigerian Constitution, separation of powers is both horizontal and vertical. As regards to the horizontal

43 J. Alder, Constitutional and Administrative Law, (London: Macmillan Publishers, $7^{\text {th }}$ Edn., 2009), p143.

44 A. A. Taiwo, Separation of Powers: A Key Principle of Democratic Governance, (Ibadan: Ababa Press Ltd., 2013), p32.

45 T. R. S. Allan, Law, Liberty and Justice: The Legal Foundations of British Constitutionalism, (Oxford: Oxford University Press, 1994), p3.

46 D.J. Levinson and R.H. Pildes, 2006, "Separation of Parties, Not Powers," Harvard Law Review, 119, p2311.

47 J.K. Nyerere, Freedom and Unity, (Dar es Salaam: Oxford University Press, 1967), p131.

48 A. Phillips, "Nigeria's Federal Financial Experience," (1971), 9 (3), The Journal of Modern African Studies, pp389-408.

49 Keyamo v. House of Assembly of Lagos, (2000) 12 NWLR, p218. 
separation of powers, the framers of this organic law carefully departmentalised governmental powers into three branches, namely - the Legislature under Section 4 of the Constitution, ${ }^{50}$ the Executive under Section 5 of the same document, ${ }^{51}$ and the Judiciary under Section $6,{ }^{52}$ in a manner that

50 In this wise, the Constitution provides that, "The legislative powers of the Federal Republic of Nigeria shall be vested in a National Assembly for the Federation, which shall consist of a Senate and a House of Representatives. The National Assembly shall have power to make laws for the peace, order and good government of the Federation or any part thereof with respect to any matter included in the Exclusive Legislative List set out in Part I of the Second Schedule to this Constitution. The power of the National Assembly to make laws for the peace, order and good government of the Federation with respect to any matter included in the Exclusive Legislative List shall, save as otherwise provided in this Constitution, be to the exclusion of the Houses of Assembly of States. In addition and without prejudice to the powers conferred by subsection (2) of this section, the National Assembly shall have power to make laws with respect to the following matters, that is to say - (a) any matter in the Concurrent Legislative List set out in the first column of Part II of the Second Schedule to this Constitution to the extent prescribed in the second column opposite thereto; and (b) any other matter with respect to which it is empowered to make laws in accordance with the provisions of this Constitution." See Section 4 (1) (2) (3) \& (4), Constitution of the Federal Republic of Nigeria, 1999.

51 On this, the Constitution provides that, "Subject to the provisions of this Constitution, the executive powers of the Federation - (a) shall be vested in the President and may subject as aforesaid and to the provisions of any law made by the National Assembly, be exercised by him either directly or through the Vice-President and Ministers of the Government of the Federation or officers in the public service of the Federation; and (b) shall extend to the execution and maintenance of this Constitution, all laws made by the National Assembly and to all matters with respect to which the National Assembly has, for the time being, power to make laws".

52 For the powers in this regard, see Section 6 (1) \& (2) of the Constitution of the Federal Republic of Nigeria, 1999 which provides that, "The judicial the separateness envisaged is clear and distinct. This is established under Part II of the Constitution, under the broad heading of 'Powers of the Federal Republic of Nigeria'. ${ }^{53}$ These provisions i.e. Sections 4, 5, and 6 of the 1999 Nigerian Constitution, are so carefully worded to protect these powers. For instance, the powers of the Legislature to makes laws for the order and good governance of Nigeria has been reaffirmed in the leading Supreme Court's decision in Attorney General of Bendel State v. Attorney General of the Federation. ${ }^{54}$ It is along these clear demarcations that each of these branches have carried out its core mandate in the development of Nigeria's constitutional democracy, and to reaffirmed the constitutionality of the doctrine, the courts have not shied away from making farreaching pronouncements on its role. It was to this end that again in Attorney General of Bendel State v. Attorney General of the Federation, ${ }^{55}$ the Supreme Court this time per Eso J.S.C., speaking of separation of powers said:

powers of the Federation shall be vested in the courts to which this section relates, being courts established for the Federation. The judicial powers of a State shall be vested in the courts to which this section relates, being courts established, subject as provided by this Constitution, for a State". See additionally Section 6 (3), (4), (5), \& (6) of the same Constitution. Note that the notion of constitutionalising judicial powers is rooted in the need to resolve complex disputes resulting from the application of the laws. See H.L.A. Hart, The Concept of Law - (Clarendon Law Series), (Oxford: Oxford University Press, $3^{\text {rd }}$ Ed., 2012), pp1-327.

53 See also Chapter V which deals extensively with the Legislature, Chapter VI, which spells out several other powers of the Executive, and Chapter VII which contains more information on Judicial powers of the State.

54 (1981) 10 SC 1 at 198.

55 (1982) 2 NCLR 509. 
Now it is time that the legislature, especially in a country like ours which has accepted the doctrine of separation of powers and which has got that doctrine embodied in constitution, is a master of its own household.

Additionally, the court opined in Unongo $v$. Aper $A k u,{ }^{56}$ that:

The Constitution of the Federal Republic of Nigeria 1979 which is hereinafter referred to as the Constitution is very unique compared with the previous Constitution in that the executive, the legislature and the judiciary are each established as a separate organ of Government. There is what can be termed a cold calculated rigidity in this separation as shown in sections 4, 5 \& 6 of the Constitution which established the legislative and the executive and the judicature respectively.

There is also a vertical separation of powers, in which powers are devolved amongst the three tiers of government, namely the Federal, State, and Local Governments. ${ }^{57}$ The notion of both horizontal and vertical separation of powers is well captured in the opinion of the Supreme Court per Rhodes - Vivour J.S.C., in Ugbav Suswan, ${ }^{58}$ where the Court said:

"The Constitution sets up a federal system by dividing powers between the federal and state governments. It establishes a national government divided into three independent branches. The executive branch makes the law, while the judiciary explains the law. There is no document superior to the Constitution in democratic governance. It is the heart and soul of the people. ",59

\section{SEPARATION OF POWERS AND THE AGE OF 'COOPERATION': EXAMIN- ING NIGERIA'S CONSTITUTIONAL PRACTICE}

(1983) 2 SC NLR 332 at 361.

57 This idea of devolution of powers can be gleaned from the provisions of Sections $2 \& 3$, Constitution of the Federal Republic of Nigeria, 1999.

58 (2005) 1 WRN 1 at 64.

59 Note 57.
Notwithstanding the departmentalisation of the powers of the three branches under the 1999 Nigerian Constitution, the operation of the document as a whole has rather shown a situation in which all three branches have their powers and responsibilities overlapping, in a manner that one cannot conclusively perform its constitutional function without the approval of one or the other two. This is in rooted in the idea of checks and balances, in which each of the branches serve as a check on the other. Scholars have opined that this framework as it can be found under American constitutional practice originally has its roots in British idea of a 'mixed regime', in which the Crown, the Lords, and the Commons were co-opted together so as to serve as a check on each other. ${ }^{60}$ However, this later gave way to the current system in which functions were separated. ${ }^{61}$

Notwithstanding the truism in this statement, present reality appear to suggest that the way and manner modern governments are designed is such that the historical delineation of powers have become significantly blurred. In fact, it has been argued that in reality, the usefulness of separation of powers is consequent upon how willing each branch of government is ready to serve as a check on the other. ${ }^{62}$ Under modern governments, powers are therefore distributed in a manner that all branches of government can complement each other's efforts towards delivering the goods of governance to the people. ${ }^{63}$ This is the invention of the idea of 'cooperation' in

60 S.G. Calabresi, M. E. Berghausen, and S. Albertson, n.4.

61 Note 59.

62 A. Appodarai, n.11.

63 D. Kyritsis, 2012, "Constitutional Review in a Representative Democracy," 32, Oxford Journal of Legal Studies, p303. 
constitutional democracies, an idea captured by Jackson, J. in Youngstown Co. v. Sawyer, ${ }^{64}$ where the United States (US) Supreme Court noted that, "While the Constitution diffuses power the better to secure liberty, it also contemplates that practice will integrate the dispersed power into a workable government ${ }^{65}$

Across the length and breadth of the global constitutional landscape, this idea of cooperation has continued to gain ascendancy, even as watertight separation of powers remains in decline. Two branches most covered in this regard are the Executive and Legislature, both of whom are the most visible branches of government, and both of whom are consistently called upon to 'cooperate,' 'join hands,' and 'complement' each-other to ensure the smooth running of government and avoid unnecessary shutdowns.

However, in Nigeria it would appear as if this idea of cooperation has been taken to the extreme. Nigeria's constitutional practice though catering for separation of powers in text, has conveniently operated a system in which the Legislature literarily bonds with the Executive, with this unholy alliance seen as a convention that every new government must follow. To make a clear distinction between this unconstitutional relationship and the developing idea of cooperation in other climes, it is important to examine how the framework of cooperation is crafted under the Nigerian constitution. In presenting this analysis, three (3) important areas in which this has been constitutionalised would be examined.

The first is the framework dealing with spending/budgetary powers under the Constitution. In this respect Section 81

64 (1952) 343 US 579.

65 Note 63. provides that, "The President shall cause to be prepared and laid before each House of the National Assembly at any time in each financial year estimates of the revenues and expenditure of the Federation for the next following financial year". ${ }^{66}$ This is one side of the framework dealing with 'power of the purse.' The other side is found in the combined provisions of Sections 59, 80, and 162 which grants powers to the Legislature to do the following - approve the budget proposal from the Executive arm, ${ }^{67}$ forbids any spending unless the approval of the Legislature has been obtained, ${ }^{68}$ extends the same to every other spending that would be made by the Executive, ${ }^{69}$ and generally put overall fiscal responsibility in a siamese twins relationship involving the Executive and Legislature. $^{70}$ In furtherance of this constitutional power, it has been argued that by reason of the Fiscal Responsibility Act,

66 Section 81 (1), Constitution of the Federal Republic of Nigeria, 1999. See additional provisions in Section 81 (2) (3) \& (4). See the provision in Section 82 where the Constitution makes provision for emergencies and empowers the President to make spending in that regard with Legislature approval, with further backing granted such 'urgent' and 'unforeseen' situations in Section 83 (1) \& (2). These provisions can also be read alongside with the provisions of Section 61 (1) of the Constitution.

67 Section 59 (1) (2) (3) (4) \& (5), Constitution of the Federal Republic of Nigeria, 1999.

68 Section 80 (1) \& (2), Constitution of the Federal Republic of Nigeria, 1999.

69 Section 80 (3), Constitution of the Federal Republic of Nigeria, 1999.

70 See Section 162 (2), Constitution of the Federal Republic of Nigeria 1999 which provides that, "The President, upon the receipt of advice from the Revenue Mobilisation Allocation and Fiscal Commission, shall table before the National Assembly proposals for revenue allocation from the Federation Account, and in determining the formula, the National Assembly shall take into account, the allocation principles especially those of population, equality of States, internal revenue generation, land mass, terrain as well as population density". 
the National Assembly is empowered, not only to approve the budgetary estimate presented by the Executive, but to alter same as it may deem necessary under the circumstances. $^{71}$

In recent times, however, the exercise of this power has come under severe criticism following series of allegations leveled against the $8^{\text {th }}$ National Assembly on the issue of 'budget padding' in the 2016 Appropriation Act. ${ }^{72}$ Specifically, the then Chairman House Committee on Appropriation, Hon. Abdulmumin Jibrin accused the Speaker and other principal officers of the House of Representatives of padding the 2016 budget to the tune of billions of naira targeted at catering for hitherto unbudgeted constituency projects. ${ }^{73} \mathrm{He}$ also stated that he resisted attempts on their part to insert about N40billion extra into the budget for personal benefits. $^{74}$ He maintained that this padding took place outside the House's main plenary sessions. ${ }^{75}$ A counter argument from the House leadership, however, pointed to the fact that the alterations were done to ensure the proper distribution of national resources to ensure that constituency projects got to every part of the country.

Budget padding has been defined as, "to dishonestly add items to bills to obtain more money". ${ }^{76}$ Even though the Constitution

71 A.O. Ekpu and P.I. Iweoha, 2017, "Powers of the Executive and Legislature in Budget Making Process in Nigeria: An Overview," 57, Journal of Law, Policy, and Globalization, pp44-54.

72 J. Odigbo, 2017, "Legislature and Budget Preparation in Nigeria: Understanding the Dilemma of Budget Padding in Nigeria," 1 (1), South East Political Science Review, pp204- 216.

73 Note 71.

74 Note 71.

75 Note 71.

76 O. Ndukwe, 2017, "Public Budgetary Process and Budget Padding: The Nigerian Experience," 5 (2), clearly provides for the budget-making process to be a joint function between the Executive and the Legislature, the contention of the Executive remains that the only role expected of the Legislature is to approve the budgetary estimate and nothing more. ${ }^{77}$ It has however been argued that this position is not tenable, as the constitutional practice across the world particularly in other African nations such as Ghana, Namibia, and Malawi show that the Legislature is indeed empowered to alter the budget. ${ }^{78}$ It would appear therefore that there is nothing unconstitutional about the way and manner the National Assembly has exercised its powers in this regard, and that in fact, when the Legislature exercises such budgetary powers, it is a clear demonstration of the doctrine of separation of powers as against just being a mere rubber stamp.

The Legislature also performs oversight functions whereby it supervises ministries, departments, and agencies of the Executive branch towards ensuring that approved budgetary estimates are adequately adhered to, as well as the execution of its legislations. ${ }^{79}$ The challenge is that often times this power of oversight has been criticised as been overtly abused by National Assembly members. ${ }^{80}$ It is however important to state that this framework is what has oiled the wheel of governance in Nigeria since the

GOUni Journal of Management and Social Sciences, pp106-115.

77 A.O. Ekpu and P.I. Iweoha, n. 70.

78 Note 76.

79 A.T. Shehu, "The Oversight Powers of the Legislature in Nigeria," in Law, Politics and Development, The Challenges of an Emerging Mega-City: Essays in Honour of Babatunde Raji Fashola, SAN, (Nigerian Bar Association, Ikeja Branch 2012), p64.

80 J.Y. Fashagba, 2009, "Legislative Oversight under the Nigerian Presidential System," The Journal of Legislative Studies, 15 (4), pp439-459. 
advent of the 1999 Nigerian Constitution. ${ }^{81}$ The consequence, therefore, is that whenever the appropriation process is mismanaged courtesy of unabating disagreements between the Legislature and Executive, the result is always monumental.

The second is the framework dealing with appointment powers under the same Constitution. In this wise, the Constitution provides for a plethora of appointments with the majority of them required to go through a rigorous process involving the approval or confirmation of the Upper Chamber of the Nigerian National Assembly, which is the Senate. ${ }^{82}$ Top on the list is the appointment of Ministers to assist the President in executing the functions of his office. ${ }^{83}$ For this class of appointments, Section 147 (2) of the Constitution provides that, "Any appointment to the office of Minister of the Government of the Federation shall, if the nomination of any person to such office is confirmed by the Senate, be made by the President". ${ }^{84}$ Similarly, the Constitution further provides for a long-list of strategic offices of the State where appointments cannot be complete without the signature of the Senate. These offices provided for in Section 153 includes the Code of Conduct

81 J. Wehner, 2002, "Parliament and the Power of the Purse: The Nigerian Constitution of 1999 in Comparative Perspective," 46 (2), Journal of African Law, pp216-231.

82 Under Nigeria's constitutional framework, there is provision for a bicameral legislature made up of a Senate of 109 members and a House of Representatives of 360 members. While the Senate is commonly referred to as the 'Upper or Red Chamber,' the House of Representatives is called the 'Lower or Green Chamber.'

83 Kuswanto, K., 2018, "Consistency of the Presidential System in Indonesia," Sriwijaya Law Review, 2(2), pp170-182.

84 Constitution of the Federal Republic of Nigeria, 1999.
Bureau, the Council of State, the Federal Character Commission, the Federal Civil Service Commission, the Federal Judicial Service Commission, the Independent National Electoral Commission, the National Defence Council, the National Economic Council, the National Judicial Council, the National Population Commission, the National Security Council, the Nigeria Police Council, the Police Service Commission, and the Revenue Mobilisation Allocation and Fiscal Commission. ${ }^{85}$

While Section 231 of the Constitution provides that in appointing any person to Office as Chief Justice of Nigeria, as well as Justices of the Supreme Court such appointments must be approved by the Senate, ${ }^{86}$ Section 238 prescribes a similar procedure for appointment to Office of President of the Court of Appeal. ${ }^{87}$ The Constitution under Section 250 mandates the same for appointment to the Office of Chief Judge of the Federal High Court; ${ }^{88}$ Section 256 for appointment to the Office of Chief Judge of the Hight Court of the Federal Capital Territory (FCT); ${ }^{89}$ Section 261 for appointment to the Office of the Grand Kadi of the Sharia Court of Appeal of the Federal Capital Territory (FCT) ${ }^{90}$ and Section 266 for appointment to the Office of the President

85 Section 153 (1), (a - n), \& Section 154 (1) (2) \& (3), Constitution of the Federal Republic of Nigeria, 1999.

86 Section 231 (1) \& (2), Constitution of the Federal Republic of Nigeria, 1999.

87 Section 238 (1), Constitution of the Federal Republic of Nigeria, 1999.

88 Section 250 (1), Constitution of the Federal Republic of Nigeria, 1999.

89 Section 256 (1), Constitution of the Federal Republic of Nigeria, 1999.

90 Section 261 (1), Constitution of the Federal Republic of Nigeria, 1999. 
of the Customary Court of Appeal of the Federal Capital Territory. ${ }^{91}$

The third is that which deals with the use of military and emergency powers under the Constitution. Depicting how power is arranged here, the Constitution under Section 5 provides that the President is forbidden from declaring a state of war on another country, without approval based on a resolution of both Houses of the National Assembly in a joint session. ${ }^{92}$ Furthermore, he cannot deploy the Armed Forces of the Federation on combat duties in or outside the country, except by the approval of the National Assembly. ${ }^{93}$ The Constitution additionally provides for cooperation as regards the general operational use of the Armed Forces under Section 217 where it states that the Armed Forces shall be for the purpose of, "suppressing insurrection and acting in aid of civil authorities to restore order when called upon to do so by the President, but subject to such conditions as may be prescribed by an Act of the National Assembly" ${ }^{94}$ The implication is that where it comes to the use of the military to maintain internal security, the power to deploy must be jointly exercised by both branches of government. Also, pursuant to Section 305 of the Constitution, the President cannot declare

91 Section 266 (1), Constitution of the Federal Republic of Nigeria, 1999.

92 Section 5 (4) (a), Constitution of the Federal Republic of Nigeria, 1999.

93 Section 5 (4) (b), Constitution of the Federal Republic of Nigeria, 1999.

94 Section 217 (2) (c), Constitution of the Federal Republic of Nigeria, 1999. See also Section 218 (4), which states that, "The National Assembly shall have power to make laws for the regulation of - (a) the powers exercisable by the President as Commander-in-Chief of the Armed Forces of the Federation; and (b) the appointment, promotion and disciplinary control of members of the armed forces of the Federation." a state of emergency in any part of the country unless such proclamation is ratified by the National Assembly. ${ }^{95}$

These three (3) are the notable areas in which the Constitution advocates Executive/Legislative cooperation. However, for a political class that view respect for the constitution with contempt, these ideals of cooperation have been promoted as grounds for Executive/Legislative illicit romance. The reality is that fusion operates in nearly every sphere of governance. Even in areas where the Constitution has not demanded cooperation, both branches of government literarily wine and dine together, pursuing the promotion and security of each other's interests. It is instructive to point out that this practice is rooted in the mode through which political power is acquired. Under Nigeria's democracy, as it is the case everywhere, power is attained through the conduct of periodic elections, where political parties as constitutionally recognised platforms are the only organisations allowed to sponsor candidates for elections. This means the idea of independent candidacy is forbidden. With their status as major stakeholders in the political process, Nigerian political parties overtime evolved as dominant forces in the unending struggle for power. They see themselves as extremely powerful that their words must be final. Given their eminent position, their goal is often times less about the Constitution, but more about how to ensure that the power that has been acquired is retained at all cost.

The experience in Nigeria is such that the moment a political party is declared victorious at the polls and assumes power, it literarily produces the leadership of both the

95 Section 305 (1) (2) \& (3), Constitution of the Federal Republic of Nigeria, 1999. 
Executive, well as Heads of both the Senate and the House of Representatives, ${ }^{96}$ something seen as a matter of right. ${ }^{97}$ In ensuring that the ruling party's interest is well secured under the new government, the party leadership pushes the dogma of party supremacy down the throat of its members, making sure that all and sundry are whipped in line as to doing the party's bidding as regards the election of both the Senate President and the Speaker of the House of Representatives. The result is that upon their emergence, these two leaders of the Legislature are expected to promote the interest of the party by supporting the President at all times, notwithstanding that such agenda may be inimical to the overall good of the country.

It was only in the year 2011 that a crack appeared in the wall of this long-established convention when Aminu Waziri Tambuwal against the choice of his party for the Office of the Speaker of the House of Representatives, teamed up with members of the main opposition party to emerge as Speaker. He later defected to the opposition and remained in office till the end of his term as the Head of a branch of government not from the ruling party. The same scenario was repeated in 2015, when Dr. Bukola Saraki

96 In addition, even as the party who won the polls produces key Legislative office such as the President of the Senate and the Speaker of the House of Representatives, it is also entitled to produce the Senate Majority Leader and the House Majority Leader, while the party who is the runner up is rewarded with the positions of Senate Minority Leader and House Minority Leader. It was only in the year 2013 that a crack appeared in the wall of this long-stablished

97 The same is the norm in nearly all other democratic countries with a leading example being the United States of America where the winning party after producing the President is most likely to produce the Speaker of the House of Representatives. and Hon. Yakubu Dogara both of the All Progressives Congress (APC) again enlisted members of the Peoples' Democratic Party (PDP), to emerge Senate President and Speaker respectively. ${ }^{98}$ With the exception of these cases, from 1999 till date Nigeria's brand of Executive/Legislative cooperation has remained a system whereby the Legislature becomes an appendage of the Executive, rubberstamping its actions without little or no check. This has rendered the whole idea of separation of powers under the country's constitutional practice of little weight. Under this sort of arrangements, the power becomes so fused and carefully managed in-house, with the sole aim of ensuring that the ruling party remains in power for as long as possible.

Scholars have argued that Nigeria's experience of prolonged Military rule in which both Executive and Legislature power was fused, contributed largely in entrenching the above system, especially when one considers the fact that most of the members of the current political class are themselves products of military rule ${ }^{99}$. It was under this atmosphere that the PDP, for instance, was able to maintain its grip on power as Nigeria's ruling party for 16 years, before it was dislodged following the victory of the APC at the 2015 General Elections. The reality is that most of those who wield powers particularly in the Executive and

98 The emergence of the duo later degenerated into an acrimonious relationship with their party leadership and the Presidency who accused them of betraying the party. The hostilities and political undercurrents later saw both defects to the opposition PDP towards the end of their tenure.

99 O. Fagbadebo and S. Francis, 2016, "Power Relations Amongst Institutions of Government in Nigeria's Presidential System of Government: Issues and Contentions," 7 (7), International Journal of Politics and Good Governance, p7. 
Legislative branches of government in Nigeria come from the same political party, and they never hide the fact that they share the same political interest and agenda. From the foregoing, it can be argued that though the Nigerian Constitution advocates separation of powers between the Executive and the Legislature, what obtains in practice is a far cry from this and its application gives more of an impression of fusion than separateness.

It is even worse at the State level, where separation of powers would appear to have been severely watered down, as most Legislative houses are virtually in the pocket of the Executive usually personified by Governors who see themselves as 'Constituted Authorities $^{100}$. In most of these States, the other two branches of government practically live at the pleasure of the Executive, a phenomenon that is carefully designed before the government even comes into being. For example, most of the State Governors have been ru-

100 A perfect area of connivance between the State Governors and State Houses of Assembly is in the area of Local Government elections which has never seen the light of the day. The State Legislature simply rubber-stamps Caretaker Committees who hold office for donkey years and who are nothing but stooges of the Governor. For more insight on the politics of State Governors that have stifled the autonomy and democratic administration of Local Governments in Nigeria, see generally K. Olufemi, 'Leadership in Administration: A Nigerian Local Government Outlook', in Institutional Administration: A Contemporary Local Government Perspective from Nigeria, (Ikeja: Malthouse Press Ltd., 2000), p49; O. Oyediran, 'Local Government as a Third Tier of Government in Nigeria: The 1976 Local Government Reforms and After, in J. Elaigwu, and R. Akindele, (eds.), Foundations of Nigerian Federalism, 1960-1995, (Jos: Institute of Governance and Social Research, 2001), pp194211; J.A.A. Ayoade, 'The Development of Democratic Local Government in Nigeria', in Local Government in Nigeria and the United States: Learning from Comparison, (Ile-Ife: Local Government Publication Series, 1995), pp19-20. mored to be the ones who personally handpick candidates to run for elections into the Legislative houses such that once they succeed at the polls, their loyalty belongs to the Governor the benefactor, who is some sort of kingmaker. This is all in a revolving rentier system in which public office is generally deployed to facilitate private interest. ${ }^{101}$ It has also perpetuated a system in which the other two branches, particularly the Legislature remain under the dominating force of the Executive. For Nigeria to reinvent its constitutional framework, therefore, this unhealthy state of affairs must give way to a proper flourishing of the system, especially one in which all three branches of government even though separate, can co-exist in a harmonious power relationship.

\section{THE SEPARATION OF POWERS VS COOPERATION DEBATE: THE JUDI- CIAL BRANCH AS AN EXCEPTION}

The reality under contemporary constitutional practice is that the doctrine of separation of powers is past its prime and has far outlived it earlier eminence. A ray of hope is, however, seen in the fact that one out of the three branches of government still appears to be separate in terms of constitutional text and practice, and this is the Judicial branch. Even though attaining the ideals of independence of the judiciary remains more of a struggle in most developing democracies given that the then colonial powers were not interested in its development, ${ }^{102}$ in most

101 O. Eme and N. Anyadike, 2012, "Ruling Parties and Democratic Consolidation: The Case of People's Democratic Party (1999-2009)," 1 (1), Review of Public Administration and Management, pp107-124.

102 Y. Vyas, 1992, "The Independence of the Judiciary: A Third World Perspective," 11 (6), Third World Legal Studies, p131. 
countries one branch that seem to enjoy some form of 'separateness' is the Judiciary. This is predicated on the fact that it is the only branch whose members or head are not professional politicians, and so do not come into office through the boobytrap of politics. Given its apolitical nature therefore, great confidence is reposed in the Judicial branch, such that it can be called upon anytime to examine the political process which produced either the Head of the Executive or the members of the Legislature. For example, in Nigeria's recent constitutional history the Judiciary in bearing its fangs has nullified key elections in which Governors had been fraudulently elected only for them to be removed from office. ${ }^{103}$ While lower courts have been active in reviewing the actions of executive and administrative bodies towards determining the true delineation of rights, duties, and obligations imposed by law, ${ }^{104}$ the apex court in the course of the fourth republic has also left no stone unturned in uphold the Constitution when necessary. ${ }^{105}$

However, this separateness and the whole idea of the independence of the Judicial branch continues to waver on shaky grounds. While on the one hand, Scholars argue that the Judicial branch itself has somehow being intruding into the powers of

${ }^{103}$ In this wise, Governors Rotimi Amaechi, Kayode Fayemi, Olusegun Mimiko, Adams Oshiomhole, were key beneficiaries amongst other. See the following stand out cases, Peter Obi v. Independent National Electoral Commission (INEC), (2007) LPELR - SC 123/2007; Mimiko v. Independent National Electoral Commission (INEC), (2012) 7 NWLR (Pt. 1300), p.538; Oshiomhole v. Independent National Electoral Commission (INEC), (2011) 18 NWLR (Pt. 1279), p493.

104 J.O. Agbana, 2006, "An Appraisal of the Doctrine of Natural Justice," 2, Fountain Quarterly Law Journal, p156.

105 R. T. Suberu, 2008, "The Supreme Court and Federalism in Nigeria," 46 (3), The Journal of Modern African Studies, pp451-485. other branches of government, ${ }^{106}$ on the other hand, even the independence of the Judiciary in Nigeria does not appear constitutionally settled. This can be seen from the provisions of Section 17 (1) (e) of the Constitution which provides that "The independence, impartiality, and integrity of Courts of Law, and easy accessibility thereto shall be secured and maintained". ${ }^{107}$ Unfortunately, this provision falls under what the Constitution refers to as 'Fundamental Objectives and Directive Principles of State Policy, ${ }^{108}$ a Chapter that is made nonjusticiable by reason of Section 6 (6) (c) of the Constitution, which renders its glowing letters on judicial independence of little or no effect. ${ }^{109}$ It can, however, be argued that since the Fundamental Objectives and Directive Principles of State Policy as a form of political contract are nothing but mere aspirations, ${ }^{110}$ the independence of the Judicial branch can still be deemed constitutionally secured in view of Section 6 of the Constitution which extensively provides for the judicial powers of the Federation. ${ }^{111}$

Current realities, however, show that notwithstanding the kind words of the

106 A.O. Nwafor, 2013, “The Lesotho Constitution and Doctrine of Separation of Powers: Reflections on the Judicial Attitude," 6 (1), African Journal of Legal Studies, pp49-68.

107 Constitution of the Federal Republic of Nigeria, 1999.

108 Chapter II, Constitution of the Federal Republic of Nigeria, 1999.

109 A.A. Olowofoyeku, 1989, "The Beleaguered Fortress: Reflections of the Independence of Nigeria's Judiciary," 33 (1), Journal of African Law, pp5571.

110 B.O. Okere, 1983, "Fundamental Objectives and Directive Principles of State Policy under the Nigerian Constitution," 32 (1), International \& Comparative Law Quarterly, pp214-228.

111 Section 6 (1) (2) (3) (4) (5) \& (6), Constitution of the Federal Republic of Nigeria, 1999. 
Constitution, Nigeria's constitutional practice still finds itself trapped in serial attempts by the political class to fuse the Judicial branch into the marriage of convenience between the Executive and Legislature. This, therefore, calls for continuous vigilance. The current framework of separateness between the judicial branch and the Executive/Legislature must be commended, while more vigilance is demonstrated. To achieve this, legal minds have continued to call attention to why the total insulation of the Judicial branch must be the business of all. According to Ikhariale, a deliberate separation of the Judiciary from the other two branches of government, is the only contrivance that can guarantee the durability of constitutionalism. ${ }^{112}$ Reinforcing this position Phillip Kurland in his brilliant work 'The Rise and Fall of the Doctrine of Separation of Powers', opined that this stature of the Judicial branch derives majorly from the collapse of the doctrine of separation of powers and its failure to live up to its foundational objectives. ${ }^{113} \mathrm{He}$ closed his thoughts by calling to remembrance the vigilance of the Judiciary which has made it the only bastion of hope for the people against the combined tyranny of the Executive and Legislature, but then warned that one can only hope that the Judiciary will continue to have the strength and will power not to go the way of all flesh. ${ }^{114}$

112 M.A. Ikhariale, 1990, "The Independence of the Judiciary under the Third Republican Constitution of Nigeria," 34 (2), Journal of African Law, pp145-158.

113 P.B. Kurland, 1986, "The Rise and Fall of the Doctrine of Separation of Powers," 85, Michigan Law Review, p611.

114 Note. 111.

\section{CONCLUSION}

This paper has examined the dilemmas confronting the doctrine of separation of powers under Nigeria's constitutional practice. It examines the historical development of the doctrine as well as its framework under the 1999 Nigerian Constitution. It analyses the doctrine through the exercise of key governmental powers such as spending/budgetary powers, appointment powers, and military/emergency powers. The paper draws the conclusion that except for the commendable independence of the judicial branch, there appears to be a fusion of powers between the Executive and Legislature, a development that has seen the Legislature tied to the apron strings of the Executive, and ensured that the former is continually dwarfed by the latter. The paper therefore concludes that for meaning development in Nigeria's constitutional practice, there is a need for the three branches to be able to exercise their powers separately, even though there may be instances where such powers may overlap for cooperation, effective working of government, and for the delivery of purposeful governance.

\section{REFERENCES}

\section{Books}

Abifarin, O. 2000. Essays on Constitutional and Administrative Law under the 1999 Constitution. Kaduna: Mofolayomi Press. 5.

Alder, J. 2009. Constitutional and Administrative Law. $7^{\text {th }}$ Edn. London: Macmillan Publishers.

Allan, T. R. S. 1994. Law, Liberty and Justice: The Legal Foundations of British Constitutionalism. Oxford: Oxford University Press.

Bradley, A.W., and K.D. Ewing. 2003. Constitutional and Administrative Law. $13^{\text {th }}$ edn. Longman. 
Carolan, E. 2009. The New Separation of Powers: A Theory of the Modern State. Oxford: Oxford University Press.

Christiano, T., and J. Christman (eds.), 2009, Contemporary Debates in Political Philosophy.

Dicey, A. V. 1959. Introduction to the Study of the Law of the Constitution. $10^{\text {th }} \mathrm{Ed}$. Macmillan Publishers.

Hart, H.L.A. 2012. The Concept of Law. $3^{\text {rd }}$ Ed. L. Green (ed). Oxford: Clarendon Press.

Locke, J. 1988. Treatise of Civil Government 366-367, 1690. Peter Laslett ed. Cambridge: Cambridge University Press.

Montesquieu, Baron de. 1989. The Spirit of Laws. A. M. Cohler et al. (eds). Cambridge: Cambridge University Press.

Moses, A. 'Separation of Powers in the Local Government: The Legislative Experience', in O. Tony (ed.), Key Issues in Local Government and Development: The Nigerian Perspective, (Enugu: Praise House Publishers, 2011).

Mowe, K.M. 2008. Constitutional Law in Nigeria. Lagos: Malthouse Press Ltd. 23.

Nyerere, J.K. 1967. Freedom and Unity. Dar es Salaam: Oxford University Press.

Otobasi, U. "The Legislative Arm in the Third Tier of Government Framework: Functions and Inter Relations', in O. Tony, (ed.), Key Issues in Local Government and Development: A Nigerian Perspective. Enugu: Praise House Publishers. 2011.

Taiwo, A. A. 2013. Separation of Powers: A Key Principle of Democratic Governance. Ibadan: Ababa Press Ltd.

Vile, M.J.C. 1998. Constitutionalism and the Separation of Powers. $2^{\text {nd }}$ edn. Indianapolis: Liberty Funds Inc.

\section{Journal Articles}

Calabresi, S.G., M. E. Berghausen, and S. Albertson. 2012. "The Rise and Fall of
Separation of Powers." Northwestern University Law Review. 106 (2).

Casper, G. 1989. "An Essay in Separation of Powers: Some Early Versions and Practices." William and Mary Law Review. 30.

Claus, L. 2005. "Montesquieu's Mistakes and the True Meaning of Separation of Powers." Oxford Journal of Legal Studies. 25.

Ekpu, A.O., and P.I. Iweoha. 2017. "Powers of the Executive and Legislature in Budget Making Process in Nigeria: An Overview." Journal of Law, Policy, and Globalization. 57.

Fashagba, J.Y. 2009. "Legislative Oversight under the Nigerian Presidential System." The Journal of Legislative Studies. 15 (4).

Ikhariale, M.A. 1990. "The Independence of the Judiciary under the Third Republican Constitution of Nigeria." Journal of African Law. 34 (2). Lessig, L. and C.R. Sunstein. 1994. "The President and the Administration." Columbia Law Review. 93.

Kuswanto, K. 2018. "Consistency of the Presidential System in Indonesia." Sriwijaya Law Review. 2 (2).

Kyritsis, D. 2012. "Constitutional Review in a Representative Democracy." Oxford Journal of Legal Studies. 32.

Levinson, D.J. and R.H. Pildes. 2006. "Separation of Parties, Not Powers." Harvard Law Review. 119.

Nurhidayatuloh, N., \& Febrian, F. 2019. "ASEAN and European Human Rights Mechanisms, What Should be Improved?." Padjadjaran Journal of Law. 6 (1).

Okere, B.O. 1983. "Fundamental Objectives and Directive Principles of State Policy under the Nigerian Constitution." International \& Comparative Law Quarterly. 32 (1).

Olowofoyeku, A.A. 1989. "The Beleaguered Fortress: Reflections of the Independence of 
Nigeria's Judiciary." Journal of African Law. 33 (1).

Phillips, A. 1971. "Nigeria's Federal Financial Experience." The Journal of Modern African Studies. 9 (3).

Shehu, A.T. "The Oversight Powers of the Legislature in Nigeria." in Law, Politics and Development, The Challenges of an Emerging Mega-City: Essays in Honour of Babatunde Raji Fashola, SAN, (Nigerian Bar Association, Ikeja Branch 2012). 64.
Strauss, P. L. 1984. "The Place of Agencies in Government: Separation of Powers and the Fourth Branch." Columbia Law Review. 84.

Wehner, J. 2002. "Parliament and the Power of the Purse: The Nigerian Constitution of 1999 in Comparative Perspective." Journal of African Law. 46 (2). 